\title{
Radioligands targeting purinergic P2X7 receptor
}

\author{
Qi-Huang Zheng* \\ Department of Radiology and Imaging Sciences, Indiana University School of Medicine, 1345 West $16^{\text {th }}$ Street, Room 208, \\ Indianapolis, IN 46202, USA \\ *Corresponding author. Tel.: +1 317-278-4671. Fax:+1 317-278-9711. E-mail address: qzheng@iupui.edu.
}

This is where the receipt/accepted dates will go; Received Month XX, 2020; Accepted Month XX, 2020 [BMCL RECEIPT]

\begin{abstract}
The purinergic P2X7 receptor (P2X7R) is an adenosine triphosphate (ATP) ligand-gated cationic channel receptor. P2X7R is closely associated with various inflammatory, immune, cancer, neurological, musculoskeletal and cardiovascular disorders. P2X7R is an interesting therapeutic target as well as molecular imaging target. This brief digest highlights the radioligands targeting P2X7R recently developed in drug discovery and molecular imaging agent development.
\end{abstract}

Keywords: Purinergic P2X7 receptor (P2X7R); Radioligands; Drug discovery; Molecular imaging; Positron emission tomography (PET); Single photon emission computed tomography (SPECT).

\section{Introduction}

The purinergic receptor $\mathrm{P} 2 \mathrm{X}$ ligand-gated ion channel type $7(\mathrm{P} 2 \mathrm{X} 7 \mathrm{R})$ is an adenosine triphosphate (ATP)gated ion-channel. ${ }^{1-3} \mathrm{P} 2 \mathrm{X} 7 \mathrm{R}$ is ubiquitously found in almost all tissues and organs of the body and highly expressed in the immune, peripheral, and central nervous systems, thus this receptor plays important roles in health and diseases. ${ }^{4-6}$ The overexpression of $\mathrm{P} 2 \mathrm{X} 7 \mathrm{R}$ is implicated in a number of downstream events in a cell-specific manner including inflammation, ATPmediated cell proliferation and death, metabolic events, and phagocytosis, and associated with a wide variety of inflammatory, immune, cancer, neurological, musculoskeletal and cardiovascular disorders. ${ }^{7-12}$ $\mathrm{P} 2 \mathrm{X} 7 \mathrm{R}$ is an attractive therapeutic target, and many P2X7R antagonists have been developed for the treatment of P2X7R-related diseases such as inflammatory, infectious, neurological, cancer and heart diseases. ${ }^{13-17}$ Consequently P2X7R has become an interesting molecular imaging target, as the development of imaging agents parallels the drug development process. ${ }^{18}$ Advanced biomedical imaging techniques positron emission tomography (PET) and single photon emission computed tomography (SPECT) are two promising molecular imaging modalities with unrivaled sensitivity for diagnosis, staging, image-guided therapy and treatment monitoring of P2X7R-associated diseases, and there is a growing interest in design and evaluation of new radioligands for noninvasive in vivo imaging of P2X7R. ${ }^{19-21}$

Since P2X7R is a key player in inflammation, and overexpression of $\mathrm{P} 2 \mathrm{X} 7 \mathrm{R}$ is closely related to neuroinflammation, which is an essential step in the progression of brain disorders such as Alzheimer's disease (AD) and Parkinson's disease (PD). ${ }^{1}$ PET is an ideal imaging technique with greater sensitivity than SPECT, which is particularly useful for studying the living brain, and the traditional imaging target in neuroinflammation is the translocator protein $18 \mathrm{kDa}$ (TSPO). ${ }^{19}$ However, PET coupled with TSPO radioligands has come with some limitations such as low receptor binding, high inter-subject variability in binding affinity, and nonspecific binding in the human brain due to TSPO polymorphism, thus the imaging scientists have turned their efforts to search for alternative biological targets like P2X7R. ${ }^{19}$ The key is to develop an useful P2X7R radioligand. The rationale of radioligand development is well complied and discussed in an expert review, this excellent review documented all considerations including target density,

This is the author's manuscript of the article published in final edited form as:

Zheng, Q.-H. (2020). Radioligands targeting purinergic P2X7 receptor. Bioorganic \& Medicinal Chemistry Letters, 30(12), 127169.

https://doi.org/10.1016/j.bmcl.2020.127169 
radioligand affinity, binding potential, selectivity for target, ligand efficacy, ability to penetrate the bloodbrain barrier (BBB), specific binding versus nonspecific binding, plasma protein binding and efflux potential, etc. in the development of PET radioligands for brain imaging, ${ }^{22}$ and the general concepts can apply to the development of $\mathrm{P} 2 \mathrm{X} 7 \mathrm{R}$ targeting radioligands. The radioligand development includes two parts: first in vitro radioligand, generally labeled in high molar activity with a $\beta$-emitting radionuclide, often tritium $\left({ }^{3} \mathrm{H}\right)$, but sometimes radioiodine like iodine-123 $\left({ }^{123} \mathrm{I}\right)$, this is the first step of radioligand development; and then in vivo radioligand, often labeled with a positron emitting radionuclide carbon-11 $\left({ }^{11} \mathrm{C}\right)$ or fluorine-18 $\left({ }^{18} \mathrm{~F}\right)$, this is the second step of radioligand development. This brief digest highlights the radioligands targeting $\mathrm{P} 2 \mathrm{X} 7 \mathrm{R}$ in drug discovery and molecular imaging agent development. P2X7R radioligands that have been developed include ${ }^{3} \mathrm{H}-,{ }^{11} \mathrm{C}$-, ${ }^{18} \mathrm{~F}$ - and ${ }^{123} \mathrm{I}$-radioligands, in which ${ }^{3} \mathrm{H}$-radioligands are used for in vitro and ex vivo evaluation like competition binding assay and autoradiography (AUR); ${ }^{11} \mathrm{C}$ - and ${ }^{18} \mathrm{~F}$-radioligands are used for ex vivo and in vivo evaluation such as AUR, biodistribution and PET imaging; and ${ }^{123}$ I-radioligand can be used for in vitro, ex vivo and in vivo evaluation including competition binding assay, AUR, biodistribution and SPECT imaging.

\section{${ }^{3} \mathrm{H}$-Radioligands targeting P2X7R}

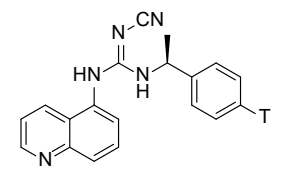

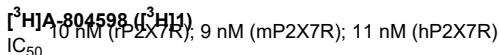

Figure 1. ${ }^{3} \mathrm{H}$-Radioligands targeting P2X7R.

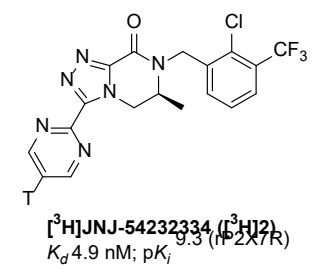

Tritium is a long half-life $\left(\mathrm{t}_{1 / 2}, 12.5 \mathrm{y}\right)$ radioisotope. ${ }^{3} \mathrm{H}$ labelled drugs are widely used for studies of drug absorption, distribution, metabolism and excretion (ADME), since the use of radiolabeled drugs is the 'gold standard' for drug discovery and development. ${ }^{23}$ Two representative $\mathrm{P} 2 \mathrm{X} 7 \mathrm{R}{ }^{3} \mathrm{H}$-radioligands $\left[{ }^{3} \mathrm{H}\right] \mathrm{A}$ 804598 ((S,E)-2-cyano-1-(1-(phenyl-4-[ $\left.\left.{ }^{3} \mathrm{H}\right]\right)$ ethyl)-3(quinolin-5-yl)guanidine, $\left.\left[{ }^{3} \mathrm{H}\right] \mathbf{1}\right)^{24}$ and $\left[{ }^{3} \mathrm{H}\right] \mathrm{NNJ}-$ 54232334 ((S)-7-(2-chloro-3-(trifluoromethyl)benzyl)6-methyl-3-(pyrimidin-2-yl-5-[ $\left.{ }^{3} \mathrm{H}\right]$ )-6,7-dihydro-

$[1,2,4]$ triazolo[4,3-a $]$ pyrazin- $8(5 H)$-one, $\left.\quad\left[{ }^{3} \mathrm{H}\right] 2\right)^{25}$ are shown in Figure 1. Radiosynthesis employed the tritiation of the bromo-precursor with $\left[{ }^{3} \mathrm{H}\right]_{2}$ under palladium catalysis to give corresponding radiolabeled products $\left[{ }^{3} \mathrm{H}\right] \mathbf{1}$ and $\left[{ }^{3} \mathrm{H}\right] \mathbf{2} .\left[{ }^{3} \mathrm{H}\right] \mathbf{1}$ is a potent and selective $\mathrm{P} 2 \mathrm{X} 7 \mathrm{R}$ antagonist with $\mathrm{IC}_{50}(\mathrm{nM})$ values 10,9 and 11 for rat P2X7R (rP2X7R), mouse P2X7R (mP2X7R) and human P2X7R (hP2X7R), respectively. $\left[{ }^{3} \mathrm{H}\right] 2\left(K_{d} 4.9\right.$ $\mathrm{nM}$ for $\mathrm{rP} 2 \mathrm{X} 7 \mathrm{R})$ is a radiolabeled $\mathrm{P} 2 \mathrm{X} 7 \mathrm{R}$ antagonist with improved properties over $\left[{ }^{3} \mathrm{H}\right] \mathbf{1}$, because $\left[{ }^{3} \mathrm{H}\right] \mathbf{2}$ has less non-specific binding, and specific binding of $\left[{ }^{3} \mathrm{H}\right] 2$ in rat brain section was markedly improved compared to $\left[{ }^{3} \mathrm{H}\right] \mathbf{1}$, in which $\left[{ }^{3} \mathrm{H}\right] \mathbf{1}$ cannot be completely displaced by $\mathrm{P} 2 \mathrm{X} 7 \mathrm{R}$ selective ligands.

\section{${ }^{11}$ C-Radioligands targeting P2X7R}

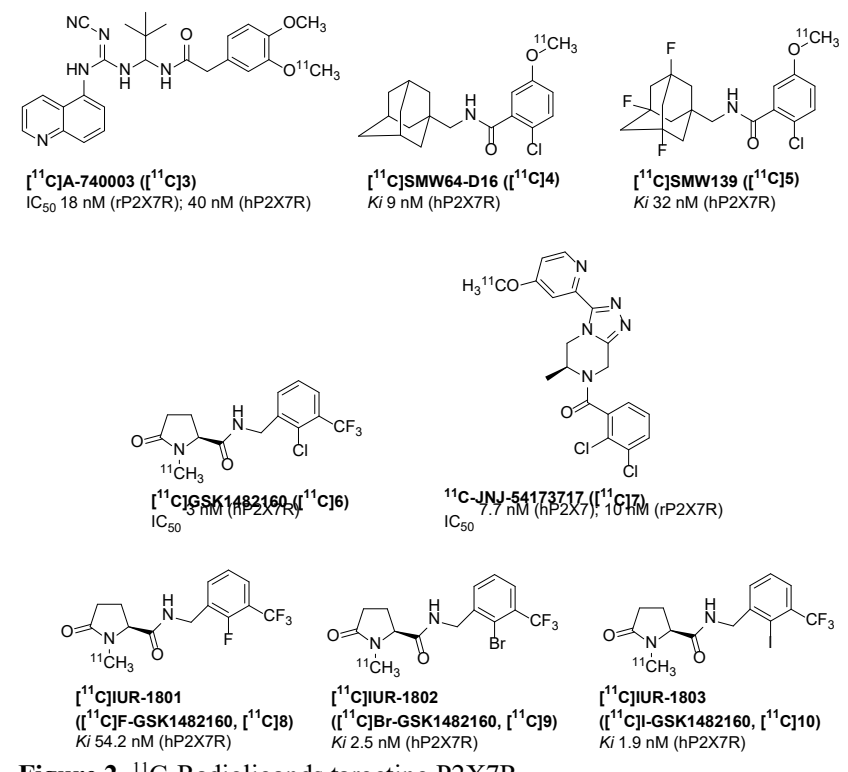

Figure 2. ${ }^{11} \mathrm{C}$-Radioligands targeting P2X7R.

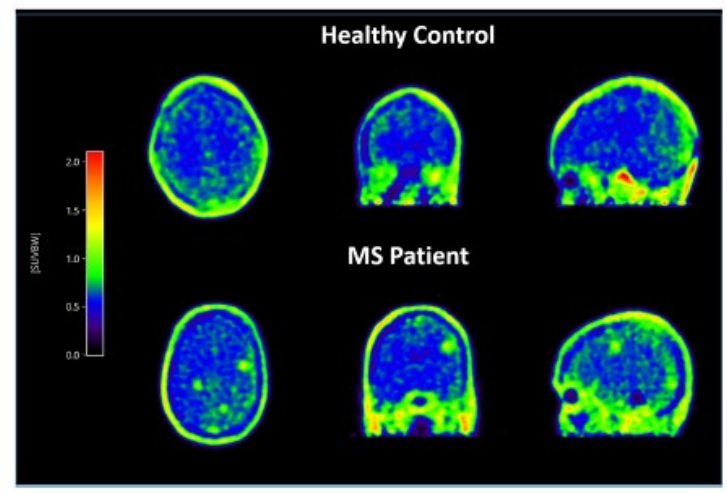

Figure 3. A $\left[{ }^{11} \mathrm{C}\right]$ SMW139-PET SUV image of one healthy control and one MS patient (Adapted from the literature ${ }^{34}$ ).

Carbon-11 is a short half-life ( $\left.\mathrm{t}_{1 / 2}, 20.4 \mathrm{~min}\right)$ PET radioisotope. Carbon-11 radiotracers have an unique advantage of back-to-back same-day studies, which can be of value when pharmacological or behavioral challenges are being studied. Carbon-11 radiotracers also have some disadvantages, for instance, their production requires an on-site cyclotron to produce radiolabeled precursor $\left[{ }^{11} \mathrm{C}\right] \mathrm{CO}_{2}$; and the imaging statistics of these radiotracers is good only for about 60 to 90 min. $\mathrm{P} 2 \mathrm{X} 7 \mathrm{R}{ }^{11} \mathrm{C}$-radioligands that have been reported over the last decade are listed in Figure 2. Radiosynthesis of P2X7R ${ }^{11} \mathrm{C}$-radioligands included two 
general approaches: $O-\left[{ }^{11} \mathrm{C}\right]$ methylation and $\mathrm{N}$ $\left.{ }^{11} \mathrm{C}\right]$ methylation of the desmethyl precursor with $\left[{ }^{11} \mathrm{C}\right]$ methyl triflate $\left(\left[{ }^{11} \mathrm{C}\right] \mathrm{CH}_{3} \mathrm{OTf}\right)$ or $\left[{ }^{11} \mathrm{C}\right]$ methyl iodide $\left(\left[{ }^{11} \mathrm{C}\right] \mathrm{CH}_{3} \mathrm{I}\right) \cdot{ }^{26,27}$

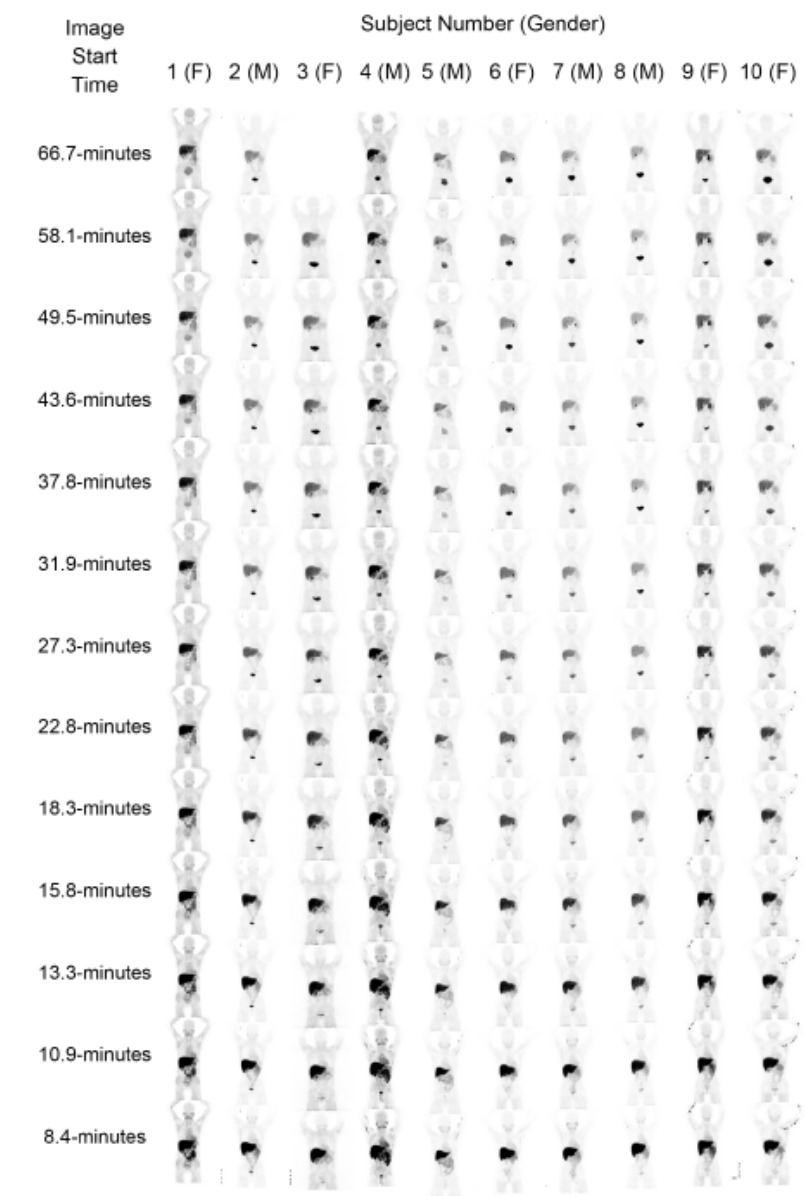

Figure 4. Sequential whole-body PET images obtained with $\left[{ }^{11} \mathrm{C}\right] \mathrm{GSK} 1482160$ in the ten normal volunteers studied, from iterative reconstructions employing the scanner's default scatter correction (Adapted from the literature ${ }^{41}$ ).

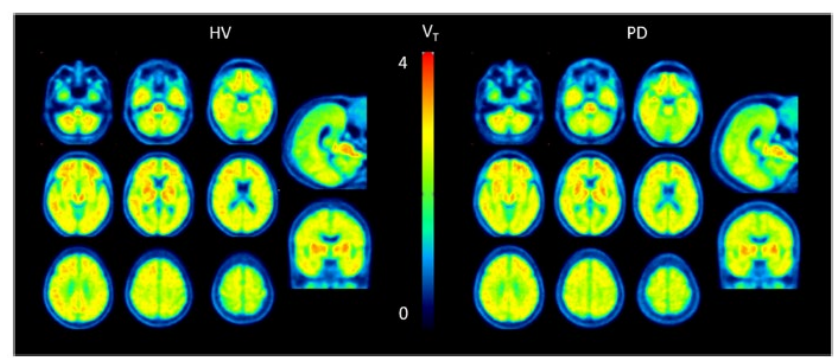

Figure 5. Average parametric LGA (Logan graphical analysis) $\mathrm{V}_{\mathrm{T}}$ (tissue volumes of distribution) ${ }^{11} \mathrm{C}-J N J 54173717-\mathrm{PET}$ images in HV and PD (Adapted from the literature ${ }^{45}$ ).

The first in vivo $\mathrm{P} 2 \mathrm{X} 7 \mathrm{R}$ radioligand appeared in the literature is $\left[{ }^{11} \mathrm{C}\right] \mathrm{A}-740003 \quad((E)-N-(1-(2-$ cyano-3(quinolin-5-yl)guanidino)-2,2-dimethylpropyl)-2-(4-

methoxy-3-([ $\left({ }^{11} \mathrm{C}\right]$ methoxy)phenyl)acetamide, $\left.\quad\left[{ }^{11} \mathrm{C}\right] 3\right)$ with $\mathrm{IC}_{50}(\mathrm{nM})$ values 18 and 40 for $\mathrm{rP} 2 \mathrm{X} 7 \mathrm{R}$ and hP2X7R, respectively, published in 2014 by Janssen et al. ${ }^{28,29}$ Their subsequent efforts have generated two other P2X7R ${ }^{11} \mathrm{C}$-radioligands $\left[{ }^{11} \mathrm{C}\right]$ SMW64-D16 $(N$ $(((3 r, 5 r, 7 r)$-adamantan-1-yl)methyl)-2-chloro-5-

$\left(\left[{ }^{11} \mathrm{C}\right]\right.$ methoxy)benzamide, $\left.\left[{ }^{11} \mathrm{C}\right] 4\right)$ and $\left[{ }^{11} \mathrm{C}\right]$ SMW139 (2-chloro-5-( $\left[{ }^{11} \mathrm{C}\right]$ methoxy)- $N-(((3 s, 5 s, 7 s)-3,5,7-$

trifluoroadamantan-1-yl)methyl)benzamide, $\left.\quad\left[{ }^{11} \mathrm{C}\right] \mathbf{5}\right)$ with $K_{i}(\mathrm{nM})$ values 9 and 32, respectively, for hP2X7R. ${ }^{30-32}$ Preclinical evaluation of $\left[{ }^{11} \mathrm{C}\right] 3$ and $\left[{ }^{11} \mathrm{C}\right] 4$ in inflammation rodent models showed low brain uptake. ${ }^{29,31}$ In vivo radiometabolite analysis of $\left[{ }^{11} \mathrm{C}\right] \mathbf{5}$ showed the highest metabolic stability in rat plasma, and $\left[{ }^{11} \mathrm{C}\right] 5$ also showed high binding to $\mathrm{hP} 2 \mathrm{X} 7 \mathrm{R}$ in vivo in a $\mathrm{hP} 2 \mathrm{X} 7 \mathrm{R}$ overexpressing rat model, but in vitro ARG study in post mortem human brain tissue with $\left[{ }^{11} \mathrm{C}\right] 5$ were unable to demonstrate a difference in tracer binding between AD patients and healthy controls. ${ }^{32,33}$ The first-in-human results concluded that uptake of $\left[{ }^{11} \mathrm{C}\right] 5$ can be quantified with PET using binding potential $\left(\mathrm{BP}_{\mathrm{ND}}\right)$ as a measure for specific binding in healthy controls $(\mathrm{n}=5)$ and patients $(\mathrm{n}=5)$ with active relapsing remitting multiple sclerosis (RRMS), but the sample size is very limited, so additional studies are needed for further clinical evaluation of $\left[{ }^{11} \mathrm{C}\right] 5$ as a novel neuroinflammation tracer. ${ }^{34} \mathrm{~A}\left[{ }^{11} \mathrm{C}\right] 5$-PET SUV (standardized uptake values) image of one healthy control and one MS patient is shown in Figure 3. ${ }^{34} \mathrm{We}$ and other group have synthesized and evaluated $\left[{ }^{11} \mathrm{C}\right] \mathrm{GSK} 1482160 \quad((S)-N$-(2-chloro-3(trifluoromethyl)benzyl)-1-([ $\left.{ }^{11} \mathrm{C}\right]$ methyl)-5-

oxopyrrolidine-2-carboxamide, $\left[{ }^{11} \mathrm{C}\right] \mathbf{6}, \mathrm{IC}_{50} 3 \mathrm{nM}$ for $\mathrm{hP} 2 \mathrm{X} 7 \mathrm{R})^{35-39}$ as a P2X7R ${ }^{11} \mathrm{C}$-radioligand. Preclinical evaluation in a lipopolysaccharide (LPS)-induced neuroinflammation mouse model ${ }^{38}$ and an experimental autoimmune encephalomyelitis (EAE) rat model as well as micro-PET study in cynomolgus macaque ${ }^{39}$ indicated $\left[{ }^{11} \mathrm{C}\right] 6$ is a promising radioligand targeting $\mathrm{P} 2 \mathrm{X} 7 \mathrm{R}$ in neuroinflammation. Production of $\left[{ }^{11} \mathrm{C}\right] 6$ as a radiopharmaceutical has been validated, ${ }^{40}$ and the estimation of radiation dosimetry for $\left[{ }^{11} \mathrm{C}\right] 6$ in normal human subjects has been reported. ${ }^{41}$ The results indicated brain uptake was low, but in most other organs the uptake and clearance of $\left[{ }^{11} \mathrm{C}\right] 6$ appears suitable for use in PET assessment of P2X7R expression as a potential marker of regional inflammation. ${ }^{41}\left[{ }^{11} \mathrm{C}\right] 6$-PET images in the ten normal volunteers are summarized in Figure $4 .{ }^{41}$ Due to this significant drawback, we continue to develop new $\mathrm{P} 2 \mathrm{X7R}{ }^{11} \mathrm{C}$-radioligands with improved properties, consequently, $\quad\left[{ }^{11} \mathrm{C}\right] I U R-1801 \quad\left(\left[{ }^{11} \mathrm{C}\right] \mathrm{F}-\mathrm{GSK} 1482160\right.$, (S)- $N$-(2-fluoro-3-(trifluoromethyl)benzyl)-1-

([ $\left.{ }^{11} \mathrm{C}\right]$ methyl)-5-oxopyrrolidine-2-carboxamide, $\left[{ }^{11} \mathrm{C}\right] \mathbf{8}$ ), $\left[{ }^{11} \mathrm{C}\right] I U R-1802\left(\left[{ }^{11} \mathrm{C}\right] \mathrm{Br}-\mathrm{GSK} 1482160,(S)-N\right.$-(2-bromo3-(trifluoromethyl)benzyl)-1-([ $\left.{ }^{11} \mathrm{C}\right]$ methyl)-5oxopyrrolidine-2-carboxamide, $\left.\left[{ }^{11} \mathrm{C}\right] 9\right)$ and $\left[{ }^{11} \mathrm{C}\right] \mathrm{IUR}$ $1803 \quad\left(\left[{ }^{11} \mathrm{C}\right] \mathrm{I}-\mathrm{GSK} 1482160, \quad(S)-N\right.$-(2-iodo-3-

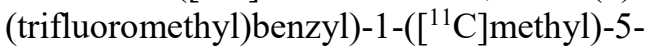


oxopyrrolidine-2-carboxamide, $\left.\left[{ }^{11} \mathrm{C}\right] \mathbf{1 0}\right)$ with $K_{i}$ (nM for hP2X7R) 54.2, 2.5 and 1.9, respectively, were synthesized. ${ }^{42}$ The initial in vitro characterization results indicate that $\left[{ }^{11} \mathrm{C}\right] \mathbf{9}$ and $\left[{ }^{11} \mathrm{C}\right] \mathbf{1 0}$ display very similar even superior P2X7R affinity to the parent radioligand $\left[{ }^{11} \mathrm{C}\right] 6$. Further biological evaluation of GSK1482160 $\left[{ }^{11} \mathrm{C}\right]$ halo-analogs $\left[{ }^{11} \mathrm{C}\right] \mathrm{IUR}-1802$ and $\left[{ }^{11} \mathrm{C}\right] \mathrm{IUR}-1803$ is currently underway. Recently, another $\mathrm{P} 2 \mathrm{X} 7 \mathrm{R}{ }^{11} \mathrm{C}$ radioligand $\quad{ }^{11} \mathrm{C}-J \mathrm{NJ} 54173717 \quad((S)-(2,3-$ dichlorophenyl)(3-(4-([ $\left.{ }^{11} \mathrm{C}\right]$ methoxy)pyridin-2-yl)-6methyl-5,6-dihydro-[1,2,4]triazolo[4,3-a]pyrazin$7(8 H)$-yl)methanone, $\left[{ }^{11} \mathrm{C}\right] 7, \mathrm{IC}_{50} 7.7$ and $10 \mathrm{nM}$ for hP2X7R and rP2X7R, respectively) has been described. ${ }^{43,44}$ Preclinical evaluation and clinical evaluation of $\left[{ }^{11} \mathrm{C}\right] 7$ have been published, and the results suggested $\left[{ }^{11} \mathrm{C}\right] 7$ is suitable for quantifying $\mathrm{P} 2 \mathrm{X} 7 \mathrm{R}$ expression in human brain, but the difference in P2X7R binding between heathy volunteers (HV) and PD patients could not be demonstrated..$^{44,45}\left[{ }^{11} \mathrm{C}\right] 7$-PET images in HV and PD are depicted in Figure 5. ${ }^{45}$ The comparison study of $\left[{ }^{11} \mathrm{C}\right] 7$ with a TSPO radioligand ${ }^{18} \mathrm{~F}$-DPA714 concluded ${ }^{18} \mathrm{~F}$-DPA714 showed increased signal while $\left[{ }^{11} \mathrm{C}\right] 7$ was not elevated in symptomatic amyotrophic lateral sclerosis (ALS) patients. ${ }^{46}$

\section{${ }^{18}$ F-Radioligands targeting P2X7R}

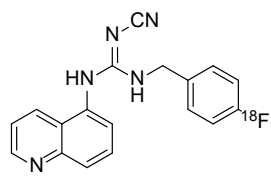

$\left[{ }^{18} \mathrm{~F}\right] \mathrm{EFB}\left(\left[^{18} \mathrm{~F}\right] 11\right)$

Ki $2.88 \mathrm{nM}$ (hP2X7R); $36.1 \mathrm{nM}$ (rP2X7R); $547 \mathrm{nM}$ (mP2X7R)
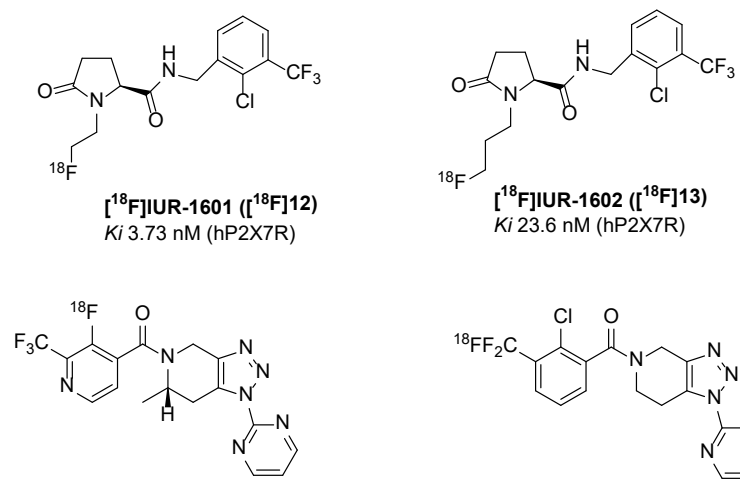

${ }^{18} \mathrm{~F}-J \mathrm{NJ}-64413739\left(\left[{ }^{18} \mathrm{~F}\right] 14\right)$

Ki $15.9 \mathrm{nM}$ (hP2X7R); $2.7 \mathrm{nM}$ (rP2X7R)

Figure 6. ${ }^{18} \mathrm{~F}$-Radioligands targeting $\mathrm{P} 2 \mathrm{X} 7 \mathrm{R}$.

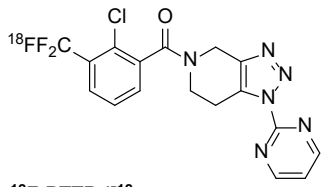

${ }^{18} \mathrm{~F}$-PTTP $\left.\left({ }^{18} \mathrm{~F}\right] 15\right)$

Ki $4.2 \mathrm{nM}(\mathrm{hP} 2 \mathrm{X} 7 \mathrm{R}) ; 6.8 \mathrm{nM}(\mathrm{rP} 2 \mathrm{X} 7 \mathrm{R})$

Fluorine-18 is another PET radioisotope with a longer half-life $\left(\mathrm{t}_{1 / 2}, 109.7 \mathrm{~min}\right)$. Fluorine-18 radiotracers have some significant advantages. For example, a fluorine-18 radioligand would be ideal for widespread use, which permits imaging of up to $5 \mathrm{~h}$ post-injection, and will result in a better match between the pharmacokinetics of binding and the physical decay of the label. The disadvantage of a fluorine-18 radiotracer is unable to use in back-to-back same-day studies because of its longer half-life. P2X7R ${ }^{18} \mathrm{~F}$-radioligands that have been developed are depicted in Figure 6. The ${ }^{18} \mathrm{~F}$ radiolabeling approach for $\mathrm{P} 2 \mathrm{X} 7 \mathrm{R}{ }^{18} \mathrm{~F}$-radioligands is a nucleophilic substitution with $\mathrm{K}\left[{ }^{18} \mathrm{~F}\right] \mathrm{F} /$ Kryptofix 2.2.2.

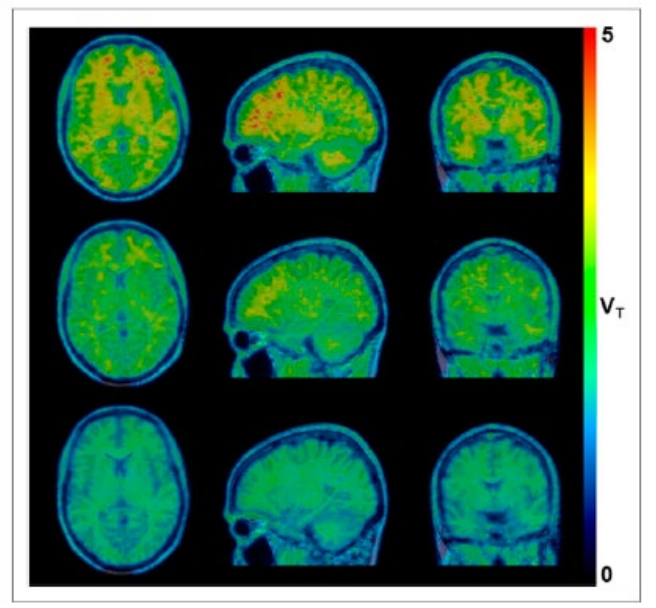

Figure 7. Representative parametric LGA $\mathrm{V}_{\mathrm{T}}$ dataset for ${ }^{18} \mathrm{~F}-\mathrm{JNJ}$ 64413739-PET scans: baseline (top row) and postdose obtained $4 \mathrm{~h}$ after dosing with $20-\mathrm{mg}$ (middle row) and 50-mg (bottom row) single doses of JNJ-54175446 (Adapted from the literature ${ }^{52}$ ).

The first reported P2X7R ${ }^{18} \mathrm{~F}$-radioligand was $\left[{ }^{18} \mathrm{~F}\right] \mathrm{EFB}$ ((E)-2-cyano-1-(4-([18 F]fluoro)benzyl)-3-(quinolin-5-

yl)guanidine, $\left.\left[{ }^{18} \mathrm{~F}\right] 11\right)$ with $K_{i}(\mathrm{nM})$ values $2.88,36.1$ and 547 for $\mathrm{hP} 2 \mathrm{X} 7 \mathrm{R}, \mathrm{rP} 2 \mathrm{X} 7 \mathrm{R}$ and $\mathrm{mP} 2 \mathrm{X} 7 \mathrm{R}$, respectively, described by Fantoni et al. ${ }^{47}$ Like $\left[{ }^{11} \mathrm{C}\right] 3$, $\left[{ }^{18} \mathrm{~F}\right] \mathbf{1 1}$ is another cyanoguanidine derivative. Preclinical evaluation of $\left[{ }^{18} \mathrm{~F}\right] \mathbf{1 1}$ showed low brain uptake in both healthy rats and LPS-rats. ${ }^{47} \mathrm{We}$ have developed two $\left[{ }^{18} \mathrm{~F}\right]$ fluoroalkyl derivatives of GSK1482160: $\quad\left[{ }^{18} \mathrm{~F}\right] \mathrm{IUR}-1601 \quad((S)-\mathrm{N}$-(2-chloro-3(trifluoromethyl)benzyl)-1-(2-([ $\left.{ }^{18} \mathrm{~F}\right]$ fluoro $)$ ethyl)-5oxopyrrolidine-2-carboxamide, $\left[{ }^{18} \mathrm{~F}\right] \mathbf{1 2}, K_{i} 3.73 \mathrm{nM}$ for hP2X7R) and [ $\left.{ }^{18} \mathrm{~F}\right] \mathrm{IUR}-1602 \quad((S)-N-(2$-chloro-3(trifluoromethyl)benzyl)-1-(3-([ $\left.{ }^{18} \mathrm{~F}\right]$ fluoro)propyl)-5oxopyrrolidine-2-carboxamide, $\left[{ }^{18} \mathrm{~F}\right] 13, K_{i} 23.6 \mathrm{nM}$ for $\mathrm{hP} 2 \mathrm{X} 7 \mathrm{R}) .{ }^{48,49}$ In vivo evaluation of $\left[{ }^{18} \mathrm{~F}\right] 12$ and $\left[{ }^{18} \mathrm{~F}\right] \mathbf{1 3}$ is in progress. Janssen $R \& D$ group has developed a promising P2X7R ${ }^{18} \mathrm{~F}$-radioligand ${ }^{18} \mathrm{~F}-\mathrm{JNJ}-64413739$ ((S)-(3-([ $\left.{ }^{18} \mathrm{~F}\right]$ fluoro)-2-(trifluoromethyl)pyridin-4-yl)(6methyl-1-(pyrimidin-2-yl)-1,4,6,7-tetrahydro- $5 \mathrm{H}$ $[1,2,3]$ triazolo[4,5-c]pyridin-5-yl)methanone, $\left.\quad\left[{ }^{18} \mathrm{~F}\right] \mathbf{1 4}\right)$ with $K_{i}(\mathrm{nM})$ values 15.9 and 2.7 for $\mathrm{hP} 2 \mathrm{X} 7 \mathrm{R}$ and rP2X7R, respectively. ${ }^{50}$ Preclinical and clinical evaluations of $\left[{ }^{18} \mathrm{~F}\right] 14$ in LPS-rats, nonhuman primate rhesus macaques, and healthy human subjects were all performed. ${ }^{50-52}$ Although in both nonhuman primate and human studies, no appropriate reference region in brain could be identified; in addition, a high inter-individual signal variability across human subjects was noticed, and the influence of genetic polymorphism on P2X7R expression level or radioligand binding property is still 
unknown, in this proof-of-concept study, they have demonstrated that $\left[{ }^{18} \mathrm{~F}\right] \mathbf{1 4}$ is a suitable PET radioligand for the quantification of $\mathrm{P} 2 \mathrm{X} 7 \mathrm{R}$ expression in the human brain. ${ }^{50-52}\left[{ }^{18} \mathrm{~F}\right] 14$-PET images in healthy male subjects are indicated in Figure $7 .^{52} \mathrm{Fu}$ et al. has reported another P2X7R ${ }^{18} \mathrm{~F}$-radioligand ${ }^{18} \mathrm{~F}-\mathrm{PTTP}((2-$ chloro-3-(difluoro( $\left[{ }^{18} \mathrm{~F}\right]$ fluoro)methyl)phenyl)(1-

(pyrimidin-2-yl)-1,4,6,7-tetrahydro- $5 \mathrm{H}$ -

$[1,2,3]$ triazolo[4,5-c]pyridin-5-yl)methanone, $\left.\quad\left[{ }^{18} \mathrm{~F}\right] \mathbf{1 5}\right)$ with $K_{i}(\mathrm{nM})$ values 4.2 and 6.8 for $\mathrm{hP} 2 \mathrm{X} 7 \mathrm{R}$ and rP2X7R, respectively. ${ }^{53,54}$ Preclinical evaluation of $\left[{ }^{18} \mathrm{~F}\right] \mathbf{1 5}$ in both inflammation mice and tumor-bearing mice was performed, and the results concluded that $\left[{ }^{18} \mathrm{~F}\right] 15$ has potential to screen new $\mathrm{P} 2 \mathrm{X} 7 \mathrm{R}$ drugs, quantify $\mathrm{P} 2 \mathrm{X} 7 \mathrm{R}$-associated peripheral inflammation, and distinguish inflammation from certain solid tumors. ${ }^{54}$

\section{${ }^{123}$ I-Radioligand targeting P2X7R}

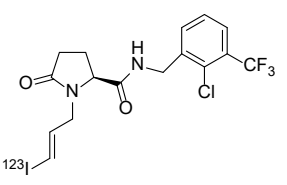

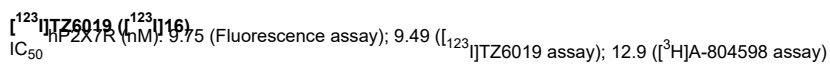
Figure 8. ${ }^{123}$ I-Radioligand targeting P2X7R.

Iodine-123 is a SPECT radioisotope with the half-life $\left(\mathrm{t}_{1 / 2}, 13.22 \mathrm{~h}\right)$. So far only one P2X7R ${ }^{123}$ I-radioligand appeared in the literature, ${ }^{55}$ as indicated in Figure 8. Radiosynthesis used the iodination of the tin precursor with $\left[{ }^{123} \mathrm{I}\right] \mathrm{NaI} .{ }^{55,56}\left[{ }^{123} \mathrm{I}\right] \mathrm{TZ6019}((S, E)-N-(2$-chloro-3(trifluoromethyl)benzyl)-1-(3-([ $\left.{ }^{123} I\right]$ iodo)allyl)-5-

oxopyrrolidine-2-carboxamide, $\left.\left[{ }^{123} \mathrm{I}\right] \mathbf{1 6}\right)$, a derivative of GSK1482160, is a potent P2X7R antagonist with 9.49$12.9 \mathrm{nM} \mathrm{IC}_{50}$ values in three different assays. In vitro characterization of $\left[{ }^{123} \mathrm{I}\right] \mathbf{1 6}$ and its response to neuroinflammation in an $\mathrm{AD}$ mouse model were performed, and the results indicated that $\left[{ }^{123} \mathrm{I}\right] 16$ has specific binding for P2X7R with low nanomolar affinity. $\left[{ }^{123} \mathrm{I}\right] \mathbf{1 6}$ could be useful for detecting the increase of $\mathrm{P} 2 \mathrm{X} 7 \mathrm{R}$ expression in brain, for in vitro assays to screen new P2X7R antagonists, and for ex vivo $\mathrm{ARG}$ to assess $\mathrm{P} 2 \mathrm{X} 7 \mathrm{R}$ expression in neuroinflammatory related diseases. ${ }^{55}$ This $\mathrm{P} 2 \mathrm{X} 7 \mathrm{R}{ }^{123} \mathrm{I}-$ radioligand can be used for in vivo SPECT imaging, and it also opens an avenue for P2X7R antagonists to be labeled with PET radioisotope iodine- $124\left(\mathrm{t}_{1 / 2}, 4.2 \mathrm{~d}\right)$ and other SPECT radioisotopes iodine- $125\left(\mathrm{t}_{1 / 2}, 59.49\right.$ d) and iodine-131 $\left(\mathrm{t}_{1 / 2}, 8.02 \mathrm{~d}\right)$.

\section{Lipophilicity of P2X7R radioligands}

The major application of $\mathrm{P} 2 \mathrm{X} 7 \mathrm{R}$ radioligands discussed here is in brain neuroinflammation imaging, and the lipophilicity is an important consideration in the development of P2X7R radioligands. The octanol-water partition coefficient (commonly expressed as LogP) is an important physical parameter directly correlated with the biological activities of a wide variety of organic compounds. ${ }^{57,58} \log \mathrm{P}$ provides an assessment of lipophilicity that often correlates with a compound's ability to penetrate the BBB. Compound lipophilicity is expressed in several different ways including terms $\log \mathrm{P}, \mathrm{C} \log \mathrm{P}, \Delta \log \mathrm{P}$, and $\log \mathrm{D} .{ }^{57}$ Table 1 gives $\log \mathrm{P}$ and calculated $\mathrm{CLog} P$ values of $\mathrm{P} 2 \mathrm{X} 7 \mathrm{R}$ radioligands in comparison with ${ }^{18} \mathrm{~F}-\mathrm{DPA} 714$ and $\left[{ }^{11} \mathrm{C}\right] \mathrm{PBR} 28 .{ }^{59,60}$ Both ${ }^{18} \mathrm{~F}$-DPA714 and $\left[{ }^{11} \mathrm{C}\right]$ PBR28 are extensively investigated TSPO radioligands in human studies. The data are easily obtained from ChemDraw Professional 18.0 (ChemOffice). It is noted that $\operatorname{LogP}$ range for compounds expected to enter the brain readily was about $1-3,{ }^{61}$ or $<5,{ }^{22}$ and the optimal range of $\log D_{7.4}$ reported for an optimum central nervous system (CNS) penetration of drug molecules was 2.0-3.5. ${ }^{57}$ As seen in Table 1, $\log \mathrm{P}$ data $(1.88-3.29)$ of PET P2X7R radioligands $\left[{ }^{11} \mathrm{C}\right] \mathrm{GSK} 1482160,\left[{ }^{11} \mathrm{C}\right] \mathrm{SMW} 139,{ }^{11} \mathrm{C}$ JNJ-54173717 and ${ }^{18} \mathrm{~F}-J \mathrm{NJ}-64413739$, which are in clinical evaluation, are in the range of $\operatorname{LogP}$ and $\log \mathrm{D}_{7.4}(1-5)$. Likewise, $\log \mathrm{P}$ data of $\left[{ }^{11} \mathrm{C}\right] \mathrm{PBR} 28$ and ${ }^{18}$ F-DPA714 (2.98 and 3.71) are also in this range. These data suggest that $\left[{ }^{11} \mathrm{C}\right] \mathrm{GSK} 1482160$, $\left[{ }^{11} \mathrm{C}\right] \mathrm{SMW} 139, \quad{ }^{11} \mathrm{C}-J \mathrm{NJ}-54173717$ and ${ }^{18} \mathrm{~F}-\mathrm{JNJ}-$ 64413739 meet $\log \mathrm{P}$ criteria and have appropriate lipophilicity for brain uptake.

Table 1. $\log \mathrm{P}$ and $\mathrm{C} \log \mathrm{P}$ of $\mathrm{P} 2 \mathrm{X} 7 \mathrm{R}$ radioligands in comparison with TSPO radioligands ${ }^{18} \mathrm{~F}-\mathrm{DPA} 714$ and $\left[{ }^{11} \mathrm{C}\right]$ PBR28.

\begin{tabular}{|c|c|c|}
\hline Compound & $\log \mathrm{P}$ & CLogP \\
\hline$\left[{ }^{3} \mathrm{H}\right] \mathrm{A}-804598\left(\left[{ }^{3} \mathrm{H}\right] \mathbf{1}\right)$ & 4.37 & 3.21 \\
\hline$\left[{ }^{3} \mathrm{H}\right] J \mathrm{NJ}-54232334\left(\left[{ }^{3} \mathrm{H}\right] 2\right)$ & 3.65 & 2.00 \\
\hline$\left[{ }^{11} \mathrm{C}\right] \mathrm{A}-740003\left(\left[{ }^{11} \mathrm{C}\right] 3\right)$ & 5.15 & 2.47 \\
\hline$\left[{ }^{11} \mathrm{C}\right]$ SMW139-D16 $\left(\left[{ }^{11} \mathrm{C}\right] 4\right)$ & 4.12 & 4.72 \\
\hline$\left[{ }^{11} \mathrm{C}\right]$ SMW139 $\left(\left[{ }^{11} \mathrm{C}\right] 5\right)$ & 2.31 & 2.90 \\
\hline$\left[{ }^{11} \mathrm{C}\right]$ GSK1482160 $\left(\left[{ }^{11} \mathrm{C}\right] 6\right)$ & 1.88 & 1.58 \\
\hline${ }^{11}$ C-JNJ-54173717 ([ $\left.\left[{ }^{11} \mathrm{C}\right] 7\right)$ & 3.29 & 2.28 \\
\hline$\left[{ }^{11} \mathrm{C}\right] \mathrm{IUR}-1801\left(\left[{ }^{11} \mathrm{C}\right] \mathbf{8}\right)$ & 1.48 & 1.21 \\
\hline$\left[{ }^{11} \mathrm{C}\right] \mathrm{IUR}-1802\left(\left[{ }^{11} \mathrm{C}\right] 9\right)$ & 2.15 & 1.93 \\
\hline$\left[{ }^{11} \mathrm{C}\right] \mathrm{IUR}-1803\left(\left[{ }^{11} \mathrm{C}\right] \mathbf{1 0}\right)$ & 2.68 & 1.71 \\
\hline$\left[{ }^{18} \mathrm{~F}\right] \mathrm{EFB}\left(\left[{ }^{18} \mathrm{~F}\right] \mathbf{1 1}\right)$ & 4.21 & 3.03 \\
\hline$\left[{ }^{18} \mathrm{~F}\right]$ IUR-1601 $\left(\left[{ }^{18} \mathrm{~F}\right] 12\right)$ & 2.07 & 2.51 \\
\hline$\left[{ }^{18} \mathrm{~F}\right]$ IUR-1602 $\left(\left[{ }^{18} \mathrm{~F}\right] 13\right)$ & 2.17 & 2.74 \\
\hline 18F-JNJ-64413739 ([ [ $\left.\left.{ }^{18} \mathrm{~F}\right] 14\right)$ & 2.09 & 1.27 \\
\hline${ }^{18} \mathrm{~F}-\mathrm{PTTP}\left(\left[{ }^{18} \mathrm{~F}\right] \mathbf{1 5}\right)$ & 2.18 & 1.12 \\
\hline$\left[{ }^{123} \mathrm{I}\right] \mathrm{TZ6019}\left(\left[{ }^{123} \mathrm{I}\right] \mathbf{1 6}\right)$ & 3.77 & 3.58 \\
\hline${ }^{18}$ F-DPA714 & 3.71 & 3.33 \\
\hline$\left[{ }^{11} \mathrm{C}\right]$ PBR28 & 2.98 & 2.71 \\
\hline
\end{tabular}

\section{Conclusion}


In summary, $\mathrm{P} 2 \mathrm{X} 7 \mathrm{R}$ targeting radioligands recently developed have been reviewed. As therapeutic drugs, P2X7R ligands (antagonists) have been extensively studied. As diagnostic imaging agents, although over a dozen P2X7R radioligands have been published over the last several years, only a few PET P2X7R radioligands are being evaluated in clinical trials, furthermore, only ${ }^{18} \mathrm{~F}-\mathrm{JNJ}-64413739$ can be used to access $\mathrm{P} 2 \mathrm{X} 7 \mathrm{R}$ expression in health and disease, to evaluate target engagement by $\mathrm{P} 2 \mathrm{X} 7 \mathrm{R}$ antagonists, and to guide dose selection. ${ }^{52}$ Most of these P2X7R PET agents have significant drawbacks like not potent enough binding affinity $K_{i}$ values, not widespread use due to short half-life of radionuclide carbon-11, limited BBB penetration and/or little brain uptake, low specific binding, complex radiosynthesis and short-term stability, and inability to confirm promising preclinical findings in a human situation. Moreover, the actual expression levels of $\mathrm{P} 2 \mathrm{X} 7 \mathrm{R}$ in humans and the difference of P2X7R expression between health and disease are not fully understood yet. Therefore, there is a huge room to develop an ideal $\mathrm{P} 2 \mathrm{X} 7 \mathrm{R}$ radioligand that can be used in the clinical setting to study P2X7R expression levels in diseases especially in neurodegenerative disorders such as $\mathrm{AD}$ and $\mathrm{PD}$.

\section{Declaration of competing interest}

The author declares that he has no conflict of interest relevant to this article.

\section{Acknowledgments}

This work was partially supported by Indiana University Showalter Young Investigator Award, Indiana University School of Medicine Biomedical Research Grant, and the Advanced Imaging Research and Technology Development (AIRTD) grants from the Department of Radiology and Imaging Sciences at Indiana University School of Medicine in the United States.

\section{References}

1. Adinolfi E, Giuliani AL, De Marchi E, Pegoraro A, Orioli E, Di Virgilio F. The P2X7 receptor: A main player in inflammation. Biochem Pharmacol. 2018;151:234-244.

2. Lister MF, Sharkey J, Sawatzky DA, Hodgkiss JP, Davidson DJ, Rossi AG, Finlayson K. The role of the purinergic $\mathrm{P} 2 \mathrm{X}_{7}$ receptor in inflammation. J Inflamm (Lond). 2007;4:5.

3. Sperlágh B, Illes P. P2X7 receptor: an emerging target in central nervous system diseases. Trends Pharmacol Sci. 2014;35:537-547.

4. Bartlett R, Stokes L, Sluyter R. The P2X7 receptor channel: recent developments and the use of $\mathrm{P} 2 \mathrm{X} 7$ antagonists in models of disease. Pharmacol Rev. 2014;66:638-675.

5. Sluyter R. The P2X7 receptor. Adv Exp Med Biol. 2017;1051:17-53.

6. Di Virgilio F, Sarti AC, Falzoni S, De Marchi E, Adinolfi E. Extracellular ATP and P2 purinergic signalling in the tumour microenvironment. Nat Rev Cancer. 2018;18:601-618.

7. Sperlágh B, Illes P. P2X7 receptor: an emerging target in central nervous system diseases. Trends Pharmacol Sci. 2014;35:537-547.

8. Bhattacharya A. Recent advances in CNS P2X7 physiology and pharmacology: Focus on neuropsychiatric disorders. Front Pharmacol. 2018;9:30.

9. Scarpellino G, Genova T, Munaron L. Purinergic P2X7 receptor: A cation channel sensitive to tumor microenvironment. Recent Pat Anticancer Drug Discov. 2019;14:32-38.

10. Aeschlimann D, Knäuper V. P2X7 receptor-mediated TG2 externalization: a link to inflammatory arthritis? Amino Acids. 2017;49:453-460.

11. Guerra Martinez C. P2X7 receptor in cardiovascular disease: The heart side. Clin Exp Pharmacol Physiol. 2019;46:513-526.

12. Miller CM, Boulter NR, Fuller SJ, Zakrzewski AM, Lees MP, Saunders BM, Wiley JS, Smith NC. The role of the $\mathrm{P}_{2} \mathrm{X}_{7}$ receptor in infectious diseases. PLoS Pathog. 2011;7:e1002212.

13. Zhang WJ, Hu CG, Zhu ZM, Luo HL. Effect of P2X7 receptor on tumorigenesis and its pharmacological properties. Biomed Pharmacother. 2020;125:109844.

14. Burnstock G, Knight GE. The potential of $\mathrm{P} 2 \mathrm{X} 7$ receptors as a therapeutic target, including inflammation and tumour progression. Purinergic Signal. 2018;14:1-18.

15. Park JH, Kim YC. P2X7 receptor antagonists: a patent review (2010-2015). Expert Opin Ther Pat. 2017;27:257-267.

16. Rech JC, Bhattacharya A, Letavic MA, Savall BM. The evolution of P2X7 antagonists with a focus on CNS indications. Bioorg Med Chem Lett. 2016;26:3838-3845.

17. Arulkumaran N, Unwin RJ, Tam FW. A potential therapeutic role for $\mathrm{P} 2 \mathrm{X} 7$ receptor (P2X7R) antagonists in the treatment of inflammatory diseases. Expert Opin Investig Drugs. 2011;20:897-915.

18. Agdeppa ED, Spilker ME. A review of imaging agent development. AAPS J. 2009;11:286-299.

19. Janssen B, Vugts DJ, Windhorst AD, Mach RH. PET imaging of microglial activation-beyond targeting TSPO. Molecules. 2018;23:E607.

20. Janssen B, Mach RH. Chapter 7, Development of brain PET imaging agents: Strategies for imaging neuroinflammation in Alzheimer's disease. Progress in Molecular Biology and Translational Science. Elsevier Inc. Volume 165, pp. 371-399, 2019.

21. Tronel C, Largeau B, Santiago Ribeiro MJ, Guilloteau D, Dupont AC, Arlicot N. Molecular targets for PET 
imaging of activated microglia: The current situation and future expectations. Int J Mol Sci. 2017;18:E802.

22. Pike VW. Considerations in the development of reversibly binding PET radioligands for brain imaging. Curr Med Chem. 2016;23:1818-1869.

23. Lockley WJS, McEwen A, Cooke R. Tritium: a coming of age for drug discovery and development ADME studies. J Labelled Comp Radiopharm. 2012;55:235-257.

24. Donnelly-Roberts DL, Namovic MT, Surber B, Vaidyanathan SX, Perez-Medrano A, Wang Y, Carroll WA, Jarvis MF. $\left[{ }^{3} \mathrm{H}\right] \mathrm{A}-804598$ ([3 $\left.\mathrm{H}\right] 2$-cyano-1-[(1S)1-phenylethyl]-3-quinolin-5-ylguanidine) is a novel, potent, and selective antagonist radioligand for $\mathrm{P} 2 \mathrm{X} 7$ receptors. Neuropharmacology. 2009;56:223-229.

25. Lord B, Ameriks MK, Wang Q, Fourgeaud L, Vliegen M, Verluyten W, Haspeslagh P, Carruthers NI, Lovenberg TW, Bonaventure P, Letavic MA, Bhattacharya A. A novel radioligand for the ATPgated ion channel P2X7: $\left[{ }^{3} \mathrm{H}\right] \mathrm{JNJ}-54232334$. Eur J Pharmacol. 2015;765:551-559.

26. Jewett DM. A simple synthesis of $\left[{ }^{11} \mathrm{C}\right]$ methyl triflate. Int J Rad Appl Instrum A. 1992;43:1383-1385.

27. Mock BH, Mulholland GK, Vavrek MT. Convenient gas phase bromination of $\left[{ }^{11} \mathrm{C}\right]$ methane and production of $\left[{ }^{11} \mathrm{C}\right]$ methyl triflate. Nucl Med Biol. 1999;26:467471.

28. Honore P, Donnelly-Roberts D, Namovic MT, Hsieh G, Zhu CZ, Mikusa JP, Hernandez G, Zhong C, Gauvin DM, Chandran P, Harris R, Medrano AP, Carroll W, Marsh K, Sullivan JP, Faltynek CR, Jarvis MF. A-740003 $\quad[N-(1-\{[$ (cyanoimino $)(5-$ quinolinylamino) methyl $]$ amino $\}-2,2-$ dimethylpropyl)-2-(3,4-dimethoxyphenyl)acetamide], a novel and selective $\mathrm{P} 2 \mathrm{X} 7$ receptor antagonist, dosedependently reduces neuropathic pain in the rat. $\mathrm{J}$ Pharmacol Exp Ther. 2006;319:1376-1385.

29. Janssen B, Vugts DJ, Funke U, Spaans A, Schuit RC, Kooijman E, Rongen M, Perk LR, Lammertsma AA, Windhorst AD. Synthesis and initial preclinical evaluation of the $\mathrm{P} 2 \mathrm{X} 7$ receptor antagonist $\left[{ }^{11} \mathrm{C}\right] \mathrm{A}$ 740003 as a novel tracer of neuroinflammation. J Labelled Comp Radiopharm. 2014;57:509-516.

30. Baxter A, Bent J, Bowers K, Braddock M, Brough S, Fagura M, Lawson M, McInally T, Mortimore M, Robertson M, Weaver R, Webborn P. Hit-to-lead studies: the discovery of potent adamantane amide P2X7 receptor antagonists. Bioorg Med Chem Lett. 2003;13:4047-4050.

31. Janssen B, Ory D, Wikinson SM, Vugts DJ, Kooijman EJ, Verbeek J, Funke U, Molenaar GT, Kruijer PS, Lammertsma AA, Kassiou M, Bormans G, Windhorst $\mathrm{AD}$. Initial evaluation of $\mathrm{P} 2 \mathrm{X}_{7} \mathrm{R}$ antagonists $\left[{ }^{11} \mathrm{C}\right] \mathrm{A}$ 740003 and $\left[{ }^{11} \mathrm{C}\right] \mathrm{SMW} 64-\mathrm{D} 16$ as PET tracers of microglial activation in neuroinflammation. J Labelled Comp Radiopharm. 2015;58:S277.

32. Janssen B, Vugts DJ, Wilkinson SM, Ory D, Chalon S, Hoozemans JJM, Schuit RC, Beaino W, Kooijman EJM, van den Hoek J, Chishty M, Doméné A, Van der
Perren A, Villa A, Maggi A, Molenaar GT, Funke U, Shevchenko RV, Baekelandt V, Bormans G, Lammertsma AA, Kassiou M, Windhorst AD. Identification of the allosteric $\mathrm{P}_{2} \mathrm{X}_{7}$ receptor antagonist $\left[{ }^{11} \mathrm{C}\right] \mathrm{SMW} 139$ as a PET tracer of microglial activation. Sci Rep. 2018;8:6580.

33. Moein MM, Tóth M, Tari L, Varrone A, Abdel-Rehim M, Halldin C. New approach in radiometabolite analysis of positron emission tomography (PET) radioligands; lead-shielded microextraction by packed sorbent as a tool for in vivo radiometabolite analysis of $\left[{ }^{11} \mathrm{C}\right] \mathrm{SMW} 139$ in rat plasma. Talanta. 2020;208:120449.

34. Hagens MHJ, Golla SSV, Janssen B, Vugts DJ, Beaino W, Windhorst AD, O'Brien-Brown J, Kassiou M, Schuit RC, Schwarte LA, de Vries HE, Killestein J, Barkhof F, van Berckel BNM, Lammertsma AA. The $\mathrm{P}_{2} \mathrm{X}_{7}$ receptor tracer $\left[{ }^{11} \mathrm{C}\right] \mathrm{SMW} 139$ as an in vivo marker of neuroinflammation in multiple sclerosis: a first-in man study. Eur J Nucl Med Mol Imaging. 2020;47:379-389.

35. Abdi MH, Beswick PJ, Billinton A, Chambers LJ, Charlton A, Collins SD, Collis KL, Dean DK, Fonfria E, Gleave RJ, Lejeune CL, Livermore DG, Medhurst SJ, Michel AD, Moses AP, Page L, Patel S, Roman SA, Senger S, Slingsby B, Steadman JG, Stevens AJ, Walter DS. Discovery and structure-activity relationships of a series of pyroglutamic acid amide antagonists of the $\mathrm{P} 2 \mathrm{X}_{7}$ receptor. Bioorg Med Chem Lett. 2010;20:5080-5084.

36. Ali Z, Laurijssens B, Ostenfeld T, McHugh S, Stylianou A, Scott-Stevens P, Hosking L, Dewit O, Richardson JC, Chen C. Pharmacokinetic and pharmacodynamic profiling of a $\mathrm{P} 2 \mathrm{X} 7$ receptor allosteric modulator GSK1482160 in healthy human subjects. Br J Clin Pharmacol. 2013;75:197-207.

37. Gao M, Wang M, Green MA, Hutchins GD, Zheng Q.-H. Synthesis of $\left[{ }^{11} \mathrm{C}\right] \mathrm{GSK} 1482160$ as a new PET agent for targeting $\mathrm{P}_{2} \mathrm{X}_{7}$ receptor. Bioorg Med Chem Lett. 2015;25:1965-1970.

38. Territo PR, Meyer JA, Peters JS, Riley AA, McCarthy BP, Gao M, Wang M, Green MA, Zheng Q.-H, Hutchins GD. Characterization of ${ }^{11} \mathrm{C}-\mathrm{GSK} 1482160$ for targeting the $\mathrm{P} 2 \mathrm{X} 7$ receptor as a biomarker for neuroinflammation. J Nucl Med. 2017;58:458-465.

39. Han J, Liu H, Liu C, Jin H, Perlmutter JS, Egan TM, $\mathrm{Tu}$ Z. Pharmacologic characterizations of a P2X7 receptor-specific radioligand, $\left[{ }^{11} \mathrm{C}\right] \mathrm{GSK} 1482160$ for neuroinflammatory response. Nucl Med Commun. 2017;38:372-382.

40. Wissmann CL, Wang M, Gao M, Zheng Q.-H, Green MA. Development, validation and implementation of radio-HPLC methods for the P2X7-receptor-targeted $\left[{ }^{11} \mathrm{C}\right] \mathrm{GSK} 1482160$ radiopharmaceutical. Appl Radiat Isot. 2018;142:8-11.

41. Green MA, Hutchins GD, Fletcher JW, Territo W, Polson H, Trussell HK, Wissmann CL, Zheng Q.-H, Gao M, Wang M, Glick-Wilson BE. Distribution of the P2X7-receptor-targeted $\quad\left[{ }^{11} \mathrm{C}\right] \mathrm{GSK} 1482160$ 
radiopharmaceutical in normal human subjects. J Nucl Med. 2018;59(S1):1009.

42. Gao M, Wang M, Meyer JA, Territo PR, Hutchins GD, Zarrinmayeh H, Zheng Q.-H. Synthesis and in vitro biological evaluation of new $\mathrm{P} 2 \mathrm{X} 7 \mathrm{R}$ radioligands $\left[{ }^{11} \mathrm{C}\right]$ halo-GSK1482160 analogs. Bioorg Med Chem Lett. 2019;29:1476-1480.

43. Rudolph DA, Alcazar J, Ameriks MK, Anton AB, Ao $\mathrm{H}$, Bonaventure P, Carruthers NI, Chrovian CC, De Angelis M, Lord B, Rech JC, Wang Q, Bhattacharya A, Andres JI, Letavic MA. Novel methyl substituted 1-(5,6-dihydro-[1,2,4]triazolo[4,3-a]pyrazin-7(8H)yl)methanones are P2X7 antagonists. Bioorg Med Chem Lett. 2015;25:3157-3163.

44. Ory D, Celen S, Gijsbers R, Van Den Haute C, Postnov A, Koole M, Vandeputte C, Andrés JI, Alcazar J, De Angelis M, Langlois X, Bhattacharya A, Schmidt M, Letavic MA, Vanduffel W, Van Laere K, Verbruggen A, Debyser Z, Bormans G. Preclinical evaluation of a $\mathrm{P} 2 \mathrm{X} 7$ receptor-selective radiotracer: PET studies in a rat model with local overexpression of the human P2X7 receptor and in nonhuman primates. J Nucl Med. 2016;57:1436-1441.

45. Van Weehaeghe D, Koole M, Schmidt ME, Deman S, Jacobs AH, Souche E, Serdons K, Sunaert S, Bormans $\mathrm{G}$, Vandenberghe $\mathrm{W}$, Van Laere K. $\left[{ }^{11} \mathrm{C}\right] J \mathrm{NJ} 54173717$, a novel P2X7 receptor radioligand as marker for neuroinflammation: human biodistribution, dosimetry, brain kinetic modelling and quantification of brain $\mathrm{P} 2 \mathrm{X} 7$ receptors in patients with Parkinson's disease and healthy volunteers. Eur J Nucl Med Mol Imaging. 2019;46:2051-2064.

46. Van Weehaeghe D, Van Schoor E, De Vocht J, Koole M, Attili B, Celen S, Declercq L, Thal DR, Van Damme P, Bormans G, Van Laere K. TSPO versus $\mathrm{P} 2 \mathrm{X} 7$ as target for neuroinflammation - an in vitro and in vivo study. J Nucl Med. 2020;61:604-607.

47. Fantoni ER, Dal Ben D, Falzoni S, Di Virgilio F, Lovestone S, Gee A. Design, synthesis and evaluation in an LPS rodent model of neuroinflammation of a novel ${ }^{18} \mathrm{~F}$-labelled PET tracer targeting P2X7. EJNMMI Res. 2017;7:31.

48. Gao M, Wang M, Glick-Wilson BE, Meyer JA, Peters JS, Territo PR, Green MA, Hutchins GD, Zarrinmayeh $\mathrm{H}$, Zheng Q.-H. Synthesis and preliminary biological evaluation of a novel $\mathrm{P} 2 \mathrm{X} 7 \mathrm{R}$ radioligand $\left[{ }^{18} \mathrm{~F}\right] \mathrm{IUR}$ 1601. Bioorg Med Chem Lett. 2018;28:1603-1609.

49. Gao M, Wang M, Glick-Wilson BE, Meyer JA, Peters JS, Territo PR, Green MA, Hutchins GD, Zarrinmayeh $\mathrm{H}$, Zheng Q.-H. Synthesis and initial in vitro characterization of a new $\mathrm{P} 2 \mathrm{X} 7 \mathrm{R}$ radioligand $\left[{ }^{18}\right.$ F]IUR-1602. Appl Radiat Isot. 2019;144:10-18.

50. Kolb HC, Barret O, Bhattacharya A, Chen G, Constantinescu C, Huang C, Letavic M, Tamagnan G, Xia CA, Zhang W, Szardenings AK. Preclinical evaluation and nonhuman primate receptor occupancy study of ${ }^{18} \mathrm{~F}-J \mathrm{NJ}-64413739$, a PET radioligand for P2X7 receptors. J Nucl Med. 2019;60:1154-1159.
51. Berdyyeva T, Xia C, Taylor N, He Y, Chen G, Huang C, Zhang W, Kolb H, Letavic M, Bhattacharya A, Szardenings AK. PET imaging of the P2X7 ion channel with a novel tracer $\left[{ }^{18} \mathrm{~F}\right] \mathrm{JNJ}-64413739$ in a rat model of neuroinflammation. Mol Imaging Biol. 2019;21:871-878.

52. Koole M, Schmidt M, Hijzen A, Ravenstijn P, Vandermeulen C, Van Weehaeghe D, Serdons K, Celen S, Bormans G, Ceusters M, Zhang W, Van Nueten L, Kolb H, de Hoon J, Van Laere K. ${ }^{18} \mathrm{~F}-J \mathrm{NJ}-$ 64413739, a novel PET ligand for the P2X7 ion channel: radiation dosimetry, kinetic modeling, testretest variability and occupancy of the $\mathrm{P} 2 \mathrm{X} 7$ antagonist JNJ-54175446. J Nucl Med. 2019;60:683690.

53. Savall BM, Wu D, De Angelis M, Carruthers NI, Ao H, Wang Q, Lord B, Bhattacharya A, Letavic MA. Synthesis, SAR, and pharmacological characterization of brain penetrant $\mathrm{P} 2 \mathrm{X} 7$ receptor antagonists. ACS Med Chem Lett. 2015;6:671-676.

54. Fu Z, Lin Q, Hu B, Zhang Y, Chen W, Zhu J, Zhao Y, Choi HS, Shi H, Cheng D. P2X7 PET radioligand ${ }^{18} \mathrm{~F}-$ PTTP for differentiation of lung tumor from inflammation. J Nucl Med. 2019;60:930-936.

55. Jin H, Han J, Resing D, Liu H, Yue X, Miller RL, Schoch KM, Miller TM, Perlmutter JS, Egan TM, Tu Z. Synthesis and in vitro characterization of a P2X7 radioligand $\left.{ }^{[23} \mathrm{I}\right] \mathrm{TZ} 6019$ and its response to neuroinflammation in a mouse model of Alzheimer disease. Eur J Pharmacol. 2018;820:8-17.

56. Mock BH, Zheng Q.-H. Chapter 28, Radiopharmaceutical chemistry: Iodination techniques. In Henkin, R.E. et al. (Editors), Nuclear Medicine, $2^{\text {nd }}$ Edition, Elsevier Inc., Philadelphia, pp 397-405. 2006.

57. Waterhouse RN. Determination of lipophilicity and its use as a predictor of blood-brain barrier penetration of molecular imaging agents. Mol Imaging Biol. 2003;5:376-389.

58. Wang X, Dong F, Miao C, Li W, Wang M, Gao M, Zheng Q.-H, Xu Z. Synthesis of carbon-11-labeled 5$\mathrm{HT}_{6} \mathrm{R}$ antagonists as new candidate PET radioligands for imaging of Alzheimer's disease. Bioorg Med Chem Lett. 2018;28:1836-1841.

59. Briard E, Zoghbi SS, Imaizumi M, Gourley JP, Shetty HU, Hong J, Cropley V, Fujita M, Innis RB, Pike VW. Synthesis and evaluation in monkey of two sensitive ${ }^{11} \mathrm{C}$-labeled aryloxyanilide ligands for imaging brain peripheral benzodiazepine receptors in vivo. J Med Chem. 2008;51:17-30.

60. Wang M, Yoder KK, Gao M, Mock BH, Xu XM, Saykin AJ, Hutchins GD, Zheng Q.-H. Fully automated synthesis and initial PET evaluation of $\left[{ }^{11}\right.$ C]PBR28. Bioorg Med Chem Lett. 2009;19:56365639.

61. Mathis CA, Wang Y, Holt DP, Huang GF, Debnath ML, Klunk WE. Synthesis and evaluation of ${ }^{11} \mathrm{C}-$ labeled 6-substituted 2-arylbenzothiazoles as amyloid imaging agents. J Med Chem. 2003;46:2740-2754. 